\title{
Customer Relationship Management and Business Intelligence
}

\author{
Aida Habul ${ }^{1}$, Amila Pilav-Velić ${ }^{1}$ and Emir Kremić ${ }^{2}$ \\ ${ }^{1}$ University of Sarajevo, \\ 2International Burch University \\ Bosnia and Herzegovina
}

\section{Introduction}

The electronic commerce (e-commerce) has significantly made changes in customer relationships. The development of nowadays technologies has enabled customers to rapidly and without difficulty collect information regarding to the supply of various products and services. It will make effortless in finding out the most best with highest quality suppliers. The client is able to choose and to decide who provides the better offer. Therefore, barging power shifts toward the customer, whose performances determine the success of the company. By applying new advanced technology, costs are reduced as well as product prices and services, and this will intensified the competitive market relations. It will affect the unfavorable position of suppliers in the relation to customers. Therefore, we could say: managing customers' needs and achieving their satisfaction has never been more important and more necessary as in the time and terms of global digitalization. However, it does not mean that the achievement of customer satisfaction in the new economy comes down to an online communication and products sales, as well as customer services. Yet, there will exist a company which will provide better update to a content of products on the web and win client's trust which will be based on the justification of who has identified the customer needs better, more effectively versus other competitors companies. Today clients have a high expectation. What they expect is continuous interaction with companies throughout different paths: web, call center, shopping center, e - mail, etc. What they expect to be understood by companies and to recognize needs, interest, preferences and purchasing habits. Direct contact with the customer's allows by Internet has resulted with more personal relations between company and customers, creating the database of consumers to monitor their activities by the company. According to Entrepreneur Magazine, today, customer are receiving 8.000 different marketing messages per day, while in year 1985 that number was 650 messages per day. Customer themselves determines, what kind of messages will receive when and how frequently. Digitalization has enabled more effective targeting and personalization. It means targeting and one to one relations which are tailored to target segments and individual customers. Accordingly, it is possible to build stronger relationships with the relevant segments (consumer digital boards), individual consumers and business partners. This digital economy has brought a new dimension to consumers and faces the company with a big challenge. Companies which do business on the Internet 
must adapt and be prepared to respond to the increasing challenges placed before, by determining to more sophisticated consumers. Those who seek to strengthen its competitive position and differentiate in relation to others, develop strategies based on clients and based on developing relationships with clients to meet their long-term satisfaction. Achieving customer satisfaction and trust does not involve offering the right product or service which will meet expectations, but delivering the "positive experience" that will result enthusiasm. If the consumer is dissatisfied with the service provided and the relationship that it has some digital companies, it can easily switch to a competitor's Web site.

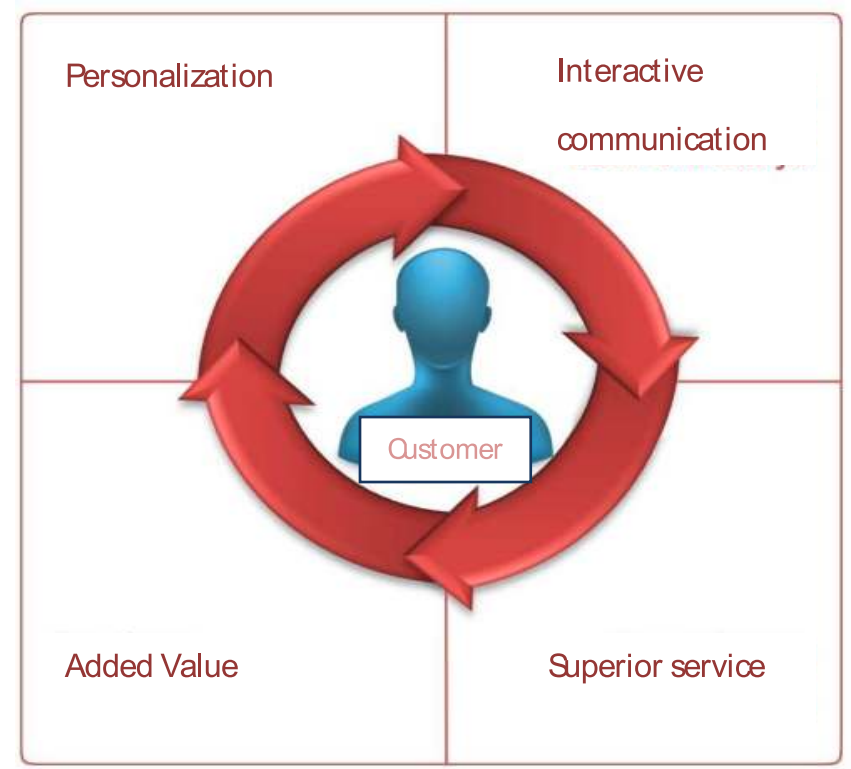

Fig. 1. Customer in focus (Source: Adapted to the definition)

According to the client position in digital enviroment, the online business strategy is concentrated on consumers and it should contain the following elements: ${ }^{1}$

- Off-line promotion through conventional ATL (Above The Line-promotional activities which includes advertising in segments of mass media) and BTL (Bellow The Linepromotional activities involving other types of promotional activities, promotional material, etc.) promotional activities;

- The company's Web site should be simple for use and searching for products information;

- To assure consumers that Web sites are safe to use and the security has met standards for secure data transaction;

${ }^{1}$ Blackwell R.D. \& Stephan K., (2001), Customers rule: why the e-commerce honeymoon is over and where winning businesses go from here, Crown Business, ISBN 0-609-60865-7, pp. 71, 140-148. 
- Identify customers who have trouble for online shopping;

- Develop relationships with customers through e-mail and other communication channels, in accordance with their wishes and preferences;

- To offer customers additional reasons for returning to the web site, for examples with a unique offers and products;

- Enable customers for online bought product to receive it physically at home address, etc.

The requirements posted by today's online customers related to the management about its relations on the web are consisted of: ${ }^{2}$

- Unambigously defined the company policy in terms of delivery of ordered products, warnity, payment issues, privacy, etc. Customers would like to know what they can expect from the companies.

- Administration of clients: Consumers would like to contorl their data to be able to access all previous interactions with the company in order to enable them for the future to have easy way of ordering and interactionsRelationships: Consumers would like that companies understand their needs and preferences up to certain level without disturbing clients privacyRead phonetically.

- Searching: Consumers prefer web sites with easy and simple navigation without any kind of confusion. In this way, probability for buying products and/or services is increasing.

- Consumers would like to have cozy shopping atmosphere without compromising on functionalities as (visual merchandising).

- Decision Support: Customers are willing to purchase when they have clear instructions and guidelines.

- Communication: Customers expect an interactive communication and to always being able to have feedback if they "lose" a navigational map, etc.

- Shopping: Customers do not want to give too many information about themselves, they want privacy but as well security and easy way to shop.

- After-sale: Consumers would like to order confirmation, access to order status and to meet delivery dates.

- It is necessary to enable the consumer into an integrated communication, communication through multiple channels of your choice.

Companies that implement e-business strategy need to realize that, although the modern information technology is indispensable in customer relationship management, customers are the power which generates most of the current and future revenues. Consumers are creating value of the company, but not the modern technological solutions. The aim of the new technology is to link technology opportunities with what consumers would like to have. The task of the new technology solutions is aligning technology performances with the needs and wishes of consumers, rather than attempt to change consumer behavior in accordance with these solutions. As we can see, the most of customer requirements are

2Burnett K., (2001), The handbook of key customer relationship management: the definitive guide to winning, managing and developing key account business, (1st edition), Financial Times Prentice Hall, ISBN: 9780273650317, Great Britain, pp. 37. 
based on an effective and interactive communication. Therefore, the provision of appropriate information to clients, but as well to understand their feedback what presents a well defined creation. Quality data and knowledge management enables the company to enhance the created value. Therefore, achieving and enhancing customer satisfaction becomes a mission impossible without the Business Intelligence applications, whose ultimate goal is value creation. In this context, this chapter aims to explore the relationship of Customer Relationship Management (CRM) and Business Intelligence (BI), and the causes and effects of their "flip-flop" connection.

\section{Need for business intelligence in the global competitive environment}

In the modern business, competition becomes more pronounced, and knowledge as a source of success of the company in the market, becomes necessary strategic choice. Information becomes a key resource and the central business function of the company that takes an active part in the virtual market. The problem of finding information has been replaced by the problem of their proper use, or whether the information quality, reliable, and can provide high-quality knowledge. Volume of information has increased, which creates certain difficulties. „Human has only 24 hours a day to deploy their attention to the millions of new effects and features, which falls on him“ (Kelly, 1999). There are many competing and contradictory sources of information, which makes their processing more difficult. In his article "Rationality as a process and product of thought" (1993), american economist G. Simon said that "information is extremely valuable when it is in small quantities, and when there are large amounts of information, it gets a negative role and diverts us from the essence". In this way, comes to "information-noise“ situations in which rational decision making is difficult, because of increased volume of redundant and incorrect information. The problem is possibility of its high quality treatment, but not the fact how to obtain information. In this regard, the role of Business Intelligence is indispensable. It facilitates the acquisition of knowledge about the factors affecting the company's operations. It is certain that in the future will be successful those organizations which have based their competitive advantage on knowledge. Companies that have specific knowledge can identify market potential and according to this, direct their vision, goals and strategies, allocate and productive use available resources. The greatest challenge of modern business is to provide the right information at the right size and shape, in a way that suits the specific needs of clients. The key to success of the company is consistent communication through all channels of interaction with clients, and a unique image and brand communications business of the company through the Internet, e-mail, electronic and print media, the physical contact center, etc. In this regard, the subject of this work is observed from the perspective of managing relationships with clients to achieve their satisfaction as the maximum value of modern companies. The future of organizations will depend on the ability of individuals, teams and entire organizations to continuously learn and increase their knowledge and inventivity. This is impossible without modern business information systems, including the concept of Business Intelligence as their upgrades, information and communication technologies and electronic networks. These elements are indispensable in building a "learning organization" which can deal with global competition, and will use the BI application as a strategic advantage. 


\subsection{Business intelligence technology}

Business Intelligence is a concept of using information technology as a tool for achieving the competitiveness of businesses, the perception of risk that occurs in the environment within the firm, and the possibility of action. This is a concept that involves the integration of traditional business functions with IT communications technologies and capabilities that are provided. The intent of BI is the integrated and coordinated application of business information in order to comprehensively improve products, service, profits and the longterm health and growth of a company. Business Intelligence and Competitive Intelligence is the process of collection, treatment, analysis and use of strategic information for a company. So, it's all about information that is important for a company. The definition is also an important segment of the treatment results and information, in case information is not usable for decisionmakers, or even worthless, means there is no difference between data and information. Also, it is useful to mention the difference between Competitive Intelligence and Business Intelligence. The first expression is much broader and includes Business Intelligence, which is more focused on software and IT tools. Effective Business Intelligence system allows data collection from all departments within the company, their analysis, preparation the necessary reports and addressing those users who are most needed. In this sense, each user gets the information that is the subject of interest and which are necessary to carry out its business activities. This aproach avoids the "information chaos" and unnecessary information overloading organizations which could result in making incorrect decisions. BI applications accelerates the process of making business decisions with respect to the quality of data located in one central place, such as Data Warehouse. It can result in useful and high-quality knowledge. On the other hand, a unique reporting system also contributes to higher quality and faster decision making, but also improve all business processes. Specifically, the system of Business Intelligence by its nature, integrates information and knowledge about customers, suppliers, competition, and overall operations. BI improves the strategic and operational planning, control, business indicators, analysis and optimization of business operations, ensuring the successful targeting customers and tracking competitive activity and predicting future trends.

\subsubsection{Business intelligence architecture}

The Business Intelligence architecture consists of three main components: Data extraction and integration, Enterprise reporting systems and Data mining 3 . This structure can be presented by the following figure:

Namely, in the most important sources of data such as OLAP (Online Analytical Processing), ERP (Enterprise Resources Planning), CRM (Customer Relationships Management), SCM (Supply Chain Management), various databases and documents arising from business processes and activities within the company. These systems are used in the processing and collection of initial data in digital form, and in their construction should strive to achieve high performance processing of data and ensure their continued availability. Transaction and enterprise resourcing planning systems are valuable in automating transactions and capturing

${ }^{3}$ Turban E., \& Volonino L., (2010.), Business Intelligence and Decision Support Systems, Information Technology for Management: Transforming Organizations in the Digital Economy, pp. 445-484, (7th edition ), John Wiley \& Sons, ISBN: 978-0470400326, USA, pp.456. 


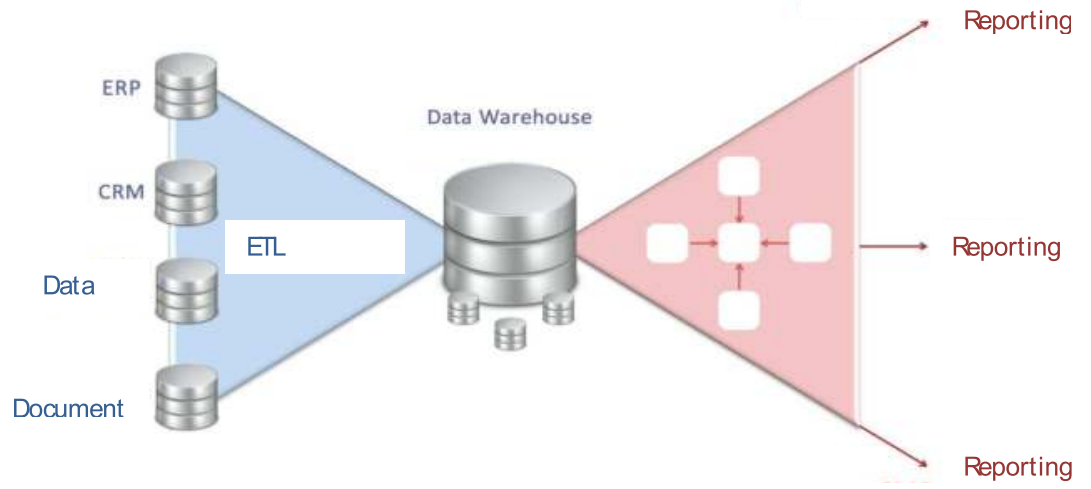

Fig. 2. Business Intelligence (Source: Adapted to the definition)

the data generated. But mostly, they do not provide information suitable for analysis and comparisons. However, these data form multiple systems that can improve companies performances and make profitable decisions. Due to different sources, data are in various formats and not standardized. Therefore, the next step consists of data standardization ETL (Extracting, Transformation, Loading) Processes of data collection and processing for system of Business Intelligence. One of three ETL processes (collection, transformation and loading) steps, for the quality of data and therefore the quality of knowledge, is a critical that the one which contains data transformation that takes the most time. The data can be used for reporting, analysis and so on. Collected and stored data must be available and integrated within the entire organization. In line with this, employees can make better decisions. For example, BI applications enable employees in the customer relations department to get information about all transactions with specific client in a short time period. They can create offer according to customers needs and aspirations. Realization of this goal can be achieved by building a functional Data Warehouse that will produce new knowledge. Therefore, in the 3.3.1. section we discuss Data Warehouse and its role in successful Customer Relationship Management. The next BI component is Enterprise Reporting Systems. It is esential to make data available to external parties but in real time. Reporting systems prepare quantitative data in a report format that might include numbers, charts and/or graphs. They provide standard, ad hoc and summary reports. "Ad hoc" reports are used when the circumstances required current and quick insight into the company's operations, without any previous preparation. Summary reports are presenting the business in a certain time period (month, quarter, year, etc.). Standard reports generated by applications that allow a certain flexibility in their construction. Their contents are the most common spreadsheet with accompanying diagrams and charts. In addition to reporting tools, there are dashboards and scorecards. Dashboards provide easy access to data and support decision making. On the other side, balanced scorecard technology is used for determining, realizing business strategy linking objectives with concrete measures. Third significant BI component are Data Mining, ad hoc and planned queries and analysis tools. These tools enable users to create queries and analyze data. Users investigate data and learn from it. Data Mining is a process that uses statistical, mathematical, artificial intelligence and machine-learning techniques to extract and identify useful information and knowledge from databases and data warehouses. It discovers intelligence from data warehouses that queries 
and reports cannot discover. Considering that better decision making is one of the main goals of BI, it is necessary to disscus Decision Support Systems (DSS) in CRM context, particularly. DSS and its role in CRM is discussed in 3.3.2. section.

\section{Business intelligence and customer relationship management}

\subsection{Importance of customer relationships management in the modern business}

In the modern economy a priority of business activities becomes a two-way communication between the company and its customers. This communication is based on the interests of both sides: companies that seek to profit, survive and grow, and customers who want to achieve added value. The most successful companies today are those that create their business processes in line with customer expectations. New business trends require company's orientation to customers. These are, primarily, grown manufacturing capacities which cause the differentiation of products and services in accordance with different customers aspirations, which brings larger volume of sales. Then, there are new technologies that facilitate the selection of companies that customers will show their confidence. This implies a simple comparison with competitive offers, low cost transition to other suppliers and customers significant time savings through continuous provision of the necessary information and offer personalized products and services. In such circumstances, the achievement of competitive advantage is an extremely difficult job. The value of customers for the company becomes invaluable. Development of information technology significantly improved the mutual relations of the company and customers. Modern information technology is a powerful medium of establishing better contacts between company personnel and clients, but also more efficient management company. Possibility of building direct relationships between companies and consumers leads to their personalization. Multi-channel communication facilitate the establishment of more sophisticated and two-way relationships, but it makes more difficult to integrate data and create unique images of clients. Companies that do not have an integrated information about customers, actually does not know their customers and can't offer personalized products and services. Due the lack of data integration, customers will need at each contact with the company to give back their data, which can cause their dissatisfaction and certain leaving. Customers will feel ignored and irrelevant to that company. For this reason, it is important that information about customers are stored in one place and available to everyone in the organization. This can be achieved by building Customer Data Warehouse. Without functional integration of Data Warehouses as the foundation, there is no successful relationship with customers or acquiring new knowledge in the form of Business Intelligence, which means providing quality information. Therefore, further we discuss importance of integrating customer information in order to achieve customer satisfaction, especially in terms of multi-channel communications and contact centers, and the role of Data Warehouse in creating a distinctive image of them.

\subsection{Contact center concept}

When Internet and new forms of communication have emerged, "Call Centers" and the phone as the primary communication channels, are being replaced by an online services as e-mail, Web, instant messaging, video calls, etc. At first the companies have tried to 
encourage customers to make orders and to purchase products over the phone. Thus, "call centers" were created to provide services for customers based on their calls (inbound calls), perform various transactions, and call the customer (outbound calls) to provide certain information or services. However, with the development of multimedia modes of communication "call centers" evolved into "contact centers", in order to increase the quality of service and achieving customers' satisfaction. The role of "call center" in customer relationship management is in establishing quality relationships with them. In this regard, the Center should be connected with other parts of the organization and other business processes within the company. At the first to clients, the web applications, e-business solutions, BI applications, internal enterprise applications and Data Warehouse as central. Contact centers have become the way of improving relationships with customers. Contact center is providing information to the clients, include deeper relationships with customers, create a better outlook of the company with technical support, suppliers, vendors, after-sale services and etc. This variety of functions requires a highly skilled and trained staff, well organized activities, effective coordination between employees, etc. On the other hand, contact center is characterized by multi-channel communication. Recent research shows that among the technologies of communication within the contact center, the most commons are e-mail, telephone, free info phone, LAN / WAN, interactive Web, VoIP, etc. This multichannel communication facilitates the establishment of bidirectional and sophisticated relationships with clients. But as well it makes difficult to integrate data and to create a unique image of clients. To be successful in "e-environment", company must continuously improve its offer and to magnify the value which is providing to customers. But, it is feasible without reliable and complete image of its customers.

\subsection{Data integration - The root of well defined customer relationship management}

Creating a comprehensive and holistic image of the customer is not possible without integrating an internal business ("back - end") applications as well as Web applications of the company. This would assume management of customer data and their integration. Data management involves the collection and use of high-quality and accurate customer data, which will allow the company to provide a positive experience to their customers. The Data Quality usually implies its applicability and usefulness in building lasting relationships with customers. In fact, many companies have a large amount of incorrect information resulting in a distorted image of the client and additional financial losses. For actual customer perceptions and expectations of their needs companies need to be efficiently integrated with customer data that are obtained from different sources. They should take advantage of every contact with the client made previously as: phone, fax, Web, e-mail, etc., and to collect as much as possible well data on them and store them in a certain "central place" where they will be available to everyone in the company. Only the combination of the most accurate and the most update information from all available sources will enable a holistic approach to clients and winning their loyalty. Due to the lack of integrated data, customers repeatedly give the same information and it could cause their frustration and dissatisfaction. Customers will feel unrecognized, ignored and irrelevant to that company. They will look for other suppliers that will offer them the expected value and where there will not be exposed to such negative experiences. In line with this, during the customer identification, there could be a lot of errors in terms of non-recognition already registered clients. So, the same client will be represented as a number of different clients, and this will prevent the creation of 
clear and comprehensive image of customer and all transactions conducted with this one will be displayed as the transactions carried out with different clients. Such omission will not ensure the establishment of good relations with customers. Lack of adequate integration of customer data will lead to unnecessary costs in the business, storing unnecessary data, sending promotional messages to the same clients, etc. Companies which have not integrated customer data, in fact, do not know their customers, and they can not offer the products and services tailored to them. Collected and stored data must be available and integrated within the entire organization, which is crucial to building quality relationships with clients. Realization of this goal is possible in terms of building a functional data warehouse which will produce a new knowledge about customers.

\subsubsection{Customer data warehouse}

Data Warehouse is the field-oriented, integrated, fixed and timeoriented set of data intended to support decision making 4 . Field-oriented of Data Warehouse means the data from the different business areas (sales, marketing, finance, etc.), which includes the Data Warehouse, and which are necessary for decision making in relation to that area. Data Warehouse must be integrated, and should include related information arising within the organization and those created in the environment of the organization. Fixity of Data Warehouses means stability in terms of data processing, because they are "loaded" from the operational database and form for analysis. This means that the answer to the same query will always be the same, regardless of the time and frequency of its generation. Data Warehouse is a timeoriented because it contains information that describes the appearance of a longer period of time, allowing comparison and prediction. Namely, the prediction of future events and processes can not be credible and well without understanding their past. Data Warehouse should contain large amounts of detailed data. Success estimation of certain business activities and communications with the environment, established and credible if all the details about them were recorded, and detailed data will enable quick response to changes in market demands. The data in the warehouse must be continuously updated and served to all employees in the company.

Data stored in information systems organizations have no value if it does not analyze, process and transform to information needed to make business decisions. Analytical processing dimensionally organized data in warehouse allows finding answers to questions, transforming data into information necessary for business decision making.It is the most prominent reason for building the data warehouse in order to better manage relationships with customers. In this way, the data warehouse is the core of CRM systems, because of data and their availability in the warehouse determine providing adequate products and/or services to clients. Companies need to implement a data warehouse which will be oriented towards customers and will contain high-quality, complete and update information. This will result in a correct decision regarding the value delivered to customers. In the existing literature, the process of building the data warehouse is determined by three processes: definition and analysis of the warehouse, then its implementation and use which is the ultimate purpose of its construction. Specifically, the process of building the warehouse

${ }^{4}$ Inmon W. H., (1996), Building the Data Warehouse, (2nd edition), John Wiley \& Sons, ISBN: 9780471141617, USA, pp.23. 
begins by defining and analyzing the reasons and requirements for data warehouse implementation. These are usually problems for whose solutions the company has no data or owns them but does not know. This latter is known as "data disorientation". Data are lost somewhere in the system, but they are not accessible. At this stage of building the warehouse, the defining the data model is decisive. The method of data storing (network, relational and hierarchical) determines the effectiveness of its use. The next step in the process of building the data warehouse is its implementation. In this process, the most significant activities are such as storing the data, defining procedures of data storage, grouping the data according to certain parameter, etc. Using the data warehouse is the last stage in its construction for the purpose of Customer Relationship Management. This includes reporting, query creation and its application in analytical and forecasting purposes. Data warehouse development influenced the emergence of a wide range of very helpful interrogatory tools, which enable to set the demanding and very complex queries. The role of the warehouses in the integration of data is invaluable. However, the most important use of data warehouses is in the analysis and forecasting which represent the basis for converting information into knowledge and business intelligence, which is of particular importance to the concept of customer relationship management. In this regard, Data Warehouse makes core of Business Intelligence system, because data and their availability in the warehouse determine the quality and effectiveness of business decisions. In addition, we discuss Decision Support Systems (DSS) in the process of achieving customer's satisfaction, with focus on their significance in the analysis and prediction of customer's behavior.

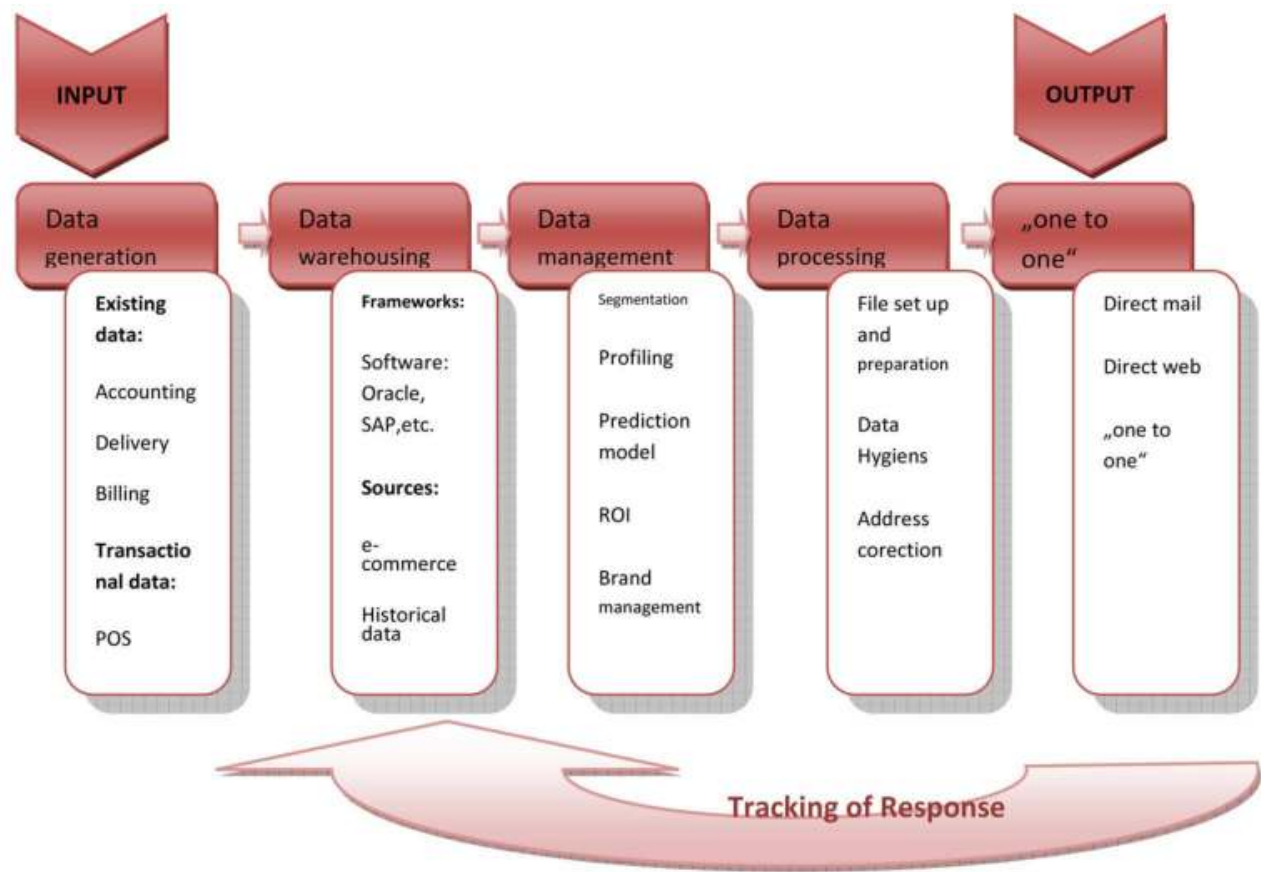

Fig. 3. Data Warehouse and data processing (Source: Adapted to the definition) 


\subsubsection{The role of decision support systems in customer relationship management}

Decision Support Systems processed information from various internal and external sources to gather information needed for decision making. The most important types of these systems are: reporting, analytical and predictive. Reporting systems usually provide answers to questions known in advance. In the CRM context, these questions are mainly related to customers' identification such as demographic characteristics, customers' needs and expectations, their habits, etc. But also, there are queries with focus on type of communication channel, attracting customers across different channels, customers' preferable channels, frequency of communication, customers' experiences with different channels, etc. However, the initial intention of using data warehouse in reporting systems is to facilitate and improve process of establishing the facts. Analytical Systems explains the results displayed in reports generated from the data warehouse. This will enable customers' segmentation and that is grouping of clients around the common features. Unlike Reporting systems, these systems provide answers to more demanding queries such as: reasons for greater costs of using one particular communication or sales channel, why customers prefer some channels, what caused that average revenue per customer declines, etc. The answers to these questions require the different methods and techniques for performing knowledge from data and business intelligence. This requires a deeper analysis that will provide a "fruitful ground" for the next phase of the decision-support system development for forecasting and/or predictive system. Predictive systems are used for the forecasting future events, or processes. Based on projections the company can anticipate certain future trends and customer behavior, and they capitalize and achieve significant competitive advantage. Trying to predict customer behavior, this will contribute superior satisfaction of their expectations, and thereby increase company profits. Therefore, this system in conjunction with data warehouses, answer the questions such as: predictions of customers' buying actions, their choice regarding communication and/or sales channels, their reactions on some new products and/or services, etc. We can notice that the role of a data warehouse is invaluable in retaining existing and attracting new customers, developing new products and services and lowering operational costs. This is the backbone of the entire information infrastructure and associated technologies for decision support. Without a functional data warehouse, there is no data integration as the foundation of successful relationships with customers, or acquiring new knowledge in the form of business intelligence. However, the need for more explicit personalized approach to customers in order to achieve their satisfaction and retention, in the recent time is quite met due to the emergence and increasingly intense use of social networking sites. Therefore, customer relationship management in modern business inevitably involves various aspects of social promotion and advertising. In line with this, the next section is focused on social networking and its advantages in customer relations.

\subsection{Social media and customer relationship management}

The increasing popularity of social networks and similar forms of communication and socializing in a virtual world, but also a large number of users and length of time they spend on these networks, provide new opportunities in business and market positioning of companies. According to the latest research of Nielsen Online company in the June 2009- 
June 2010, the time spent on social networks is $43 \%$ more than in the previous year 5 . Namely, Americans spend nearly a quarter of their time online on social networking sites and blogs. In June 2009, they spent 15.8 \% and in June $201022.7 \%$ of their online time on social networks. According to this, monthly time spent on social networks and blogs is 906 millions of hours. The second most popular Internet sector are games with 407 millions of hours, followed by e-mail with 329 millions of hours, portals, instant messaging, etc. Modern companies recognize the potential of social networks in the customer relationship management. Social networks or as often called "social media" have replaced conventional methods of communication such as print media, television, etc. This is because of lower costs, the greater possibility of targeting visitors, as well as direct and two-way communication with target group of users and potential customers. In addition, we must not forget the power of recommendations (word of mouth) what is particulary evident in using social media. The friends and members of the same "group", exchange information and "positive experiences". Companies that provide high value can use this fact as advantage in building better customer service. They can create their own user profiles and group of clients, and thus get feedback and knowledge about the perceptions and experiences of clients, which represents a good basis for creating new and effective CRM strategy and holistic performance in the market. Most important benefits that companies realize using social networks as communication channel with customers are:

- Building a network of followers who promote a company's product or brand. Brand advocates are the best promoters of the company, as they do from their own beliefs. Widgets, surveys or applications on social networks, do not require many resources and when those tools are properly designed users will not even notice that they are exposed to marketing messages or that they participate in market research. These applications users see as recommendations of their friends, what is favorable for achieving confidential customer relationships.

- Search Engine Optimization. Sharing content through social media is, in fact, free advertising, which also increase visibility of companies in the Web browsers, such as Google, Yahoo, Bing and others, and that can result in higher sales volume.

- Social Media Brand Monitoring. Using the analytical tools for brand monitoring and direct communication, companies get feedback about what users think about their product or brand.

- Aqusition. Growing number of users of social networks, enabling company to connect with a large number of organizations and individuals. In that way company expand existing customer base. However, investments in social media are still inadequate, but moving forward. At the beginning of 2009 Forrester Research published a study conducted over a hundred major companies in the world. The results show that $53 \%$ of them intend, regardless of the current economic crisis, to increase investment in "social media". According to a study CMO Survey 2009, $3.5 \%$ of the marketing budget is spent on "social media" and there is prediction that within 12 months, in 2010, will increase to $6.1 \%$ and within five years to $13,7 \%$. Concepts such as "local social advertising," "social

${ }^{5}$ Nielsen company, (August 2, 2010), What Americans Do Online: Social Media And Games Dominate Activity, Nielsen Online, 07/15/2011, Available from:

http://blog.nielsen.com/nielsenwire/online_mobile/what-americans-do-online-social-media-andgames-dominate-activity/ 
search" and "social networks" will become key issues in the future. Using social media company will improve communication with customers. Relationships will become more direct and personalized. A company that recognizes advantages and posibilities of social media in market performance can expect greater customers commitment.

\subsection{With business intelligence to the satisfied customers}

Quality knowledge management improves the quality of products, promotional sales and increases profits and customer satisfaction results. Therefore, we can say that the ultimate goal of knowledge management is to increase customer satisfaction. Business Intelligence is the ultimate purpose of knowledge management and a "way of delivery of the right information in the right format, at the right hand and the right time" (Murfitt, 2001). It does not involve the generation of larger quantities, but the provision of better and quality information. In line with this, data mining techniques have been adopted. These techniques involve alghorithms in order to obtain useful information and knowledge. The discovered knowledge represents a solid base for customers profiling and segmentation according to their habits, attitudes and behaviour. Data mining and machine learning techniques can handle large amounts of data, so they facilitate decision making processes and stimulate automatic generation of customers model. This is extremely significant BI feature considering that information about customers grows and transforms with each customer interaction. Thus, a progressive customer relationship management is enabled by BI applications and solutions which becomes the foundation of a successful customer intimacy strategy. Therefore, the most prominent advantage of Business Intelligence in customer relationship management is its rooting in personalization. Personalization of relations between company and customers is helping company to better understand and respond to the needs of each customer. This ensures that each customer gets exactly what wants and when it wants. BI applications support the implementation of various channels of communication with clients, such as e-mail, Web, telephone, etc. Customers in accordance with their preferences, choose the channel that best suits them and by whom will receive a personalized message. Before we illustrate which of the CRM area represents the strongest link between CRM and BI solutions, we will refresh the knowledge about three main building blocks within CRM. Namely, the CRM solution is based on:

- Operational CRM includes daily communication with clients. It provides support for "front office" business processes, such as sales, marketing and service departments within the company. This system gives employees immediate access to important information about the customer (information about the purchased products, prior contacts and problems, etc.), and eliminates the need for obtaining such information directly from customers.

- Analytical CRM means the collection, storage, extraction, processing, reporting and interpreting customer data. The advantage of these applications is the use of data from multiple sources and their interpretation through appropriate procedures, depending on the needs and purposes which are trying to achieve.

- Collaborative CRM involves all company's interactions with external entities, such as its customers, suppliers and partners. When customers communicate with the company they are able to see only the collaborative CRM, which includes all channels of interaction with them. Those are: offices, telephone contacts, e-mail, web pages, contacts, etc. The established contacts generate operational data that represent the basis of their analysis through analytical CRM. 
As we can notice, connection between BI applications and CRM is the most pronounced within analytical CRM, given that customers related data analysis tools need management support. A consistent and complete image of customer depends of integrated data warehouse called the Customer Data Warehouse. Customer Data Warehouse should contain large amounts of detailed data. It requires adequately designed ETL processes and scalable data warehouse. This integration between CRM and BI is shown at Figure 4.

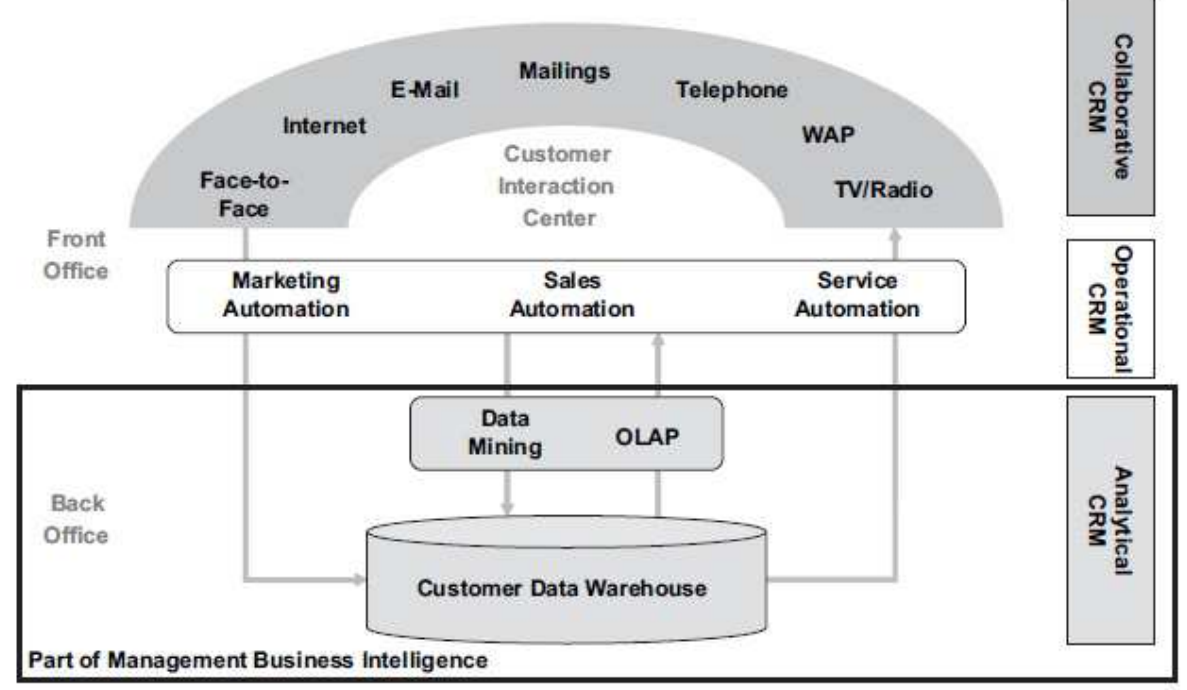

Fig. 4. Customer relationship management and Business intelligence (Source: Baars \& Kemper, 2008; Hippner \& Wilde, 2004.)

However, integration of BI modern technologies and CRM systems, provides the path to customer's loyalty. By possession of full information about all transactions and customer's experience, companies can increase the delivered value. On the other hand, Business Intelligence helps creation of real and complete image that will ensure the customer faster, better and easier decision making. Complementary use of CRM systems and Business Intelligence provides a holistic approach to customers which includes improvements in customer profiling, simpler detection value for customers, measuring the success of the company in satisfying its customers. Use of CRM and BI solutions also create a comprehensive customer relationship management and not just passive response to their requests, and predicting, and shaping their behavior. Business Intelligence can detect various incentives to increase sales and revenue, such as faster conversion of potential into actual clients, reducing the number of outgoing customers and increase sales to existing customers. Therefore, in the modern business, CRM can not be considered separately from Business Intelligence. They constitute a unique model that enables companies forecast customer behavior and make decisions based on these forecasts, and build long-term and profitable customer relationships. 


\section{Potential directions of the customer relationship management's evolution}

Digital economy, or the economy based on electronic data exchange, is definitely something what will represent an increasingly important aspect of modern business. Customer Relationship Management is a concept that has experienced a boom during the exponential growth of the internet. Personalization and direct interaction with customers, which the Internet has provided, have enabled companies for successfully and profitable satisfying their customers. Due to the development of ICT (Information-communication technology), especially Internet technology and increasingly demanding and sophisticated clients, modern companies are integrated with each other working as virtual corporations that perform only what they do best within the supply chain. Companies with an integrated value chain can provide superior service, with their biggest competitive advantage. Clients in these conditions may achieve additional values such as: prompt and accurate delivery, attractive prices, high quality, after-sale services, etc. This requires the electronic communication within the entire business process. This integration of business activities and information flows is achieved by implementing a new business model - a virtual network value. This model can be very effective, but represents a significant risk in terms of choice of partners in the chain. Specifically, the strength of the chain is determined by the strength of its weakest link. For this reason, virtual networks need to manage the company's strongest, namely those who possess the most valuable information and knowledge about customers. Among the partners there should be a great confidence, considering that companies within the same chain of sharing all information about products and services, customers and markets. Managing relationships with customers and partners within the value chain becomes a key to the success of the company in a modern economy. This integration of business activities and information flows is achieved by implementing a new business model - a Virtual Value Network ${ }^{6}$. This model can be very effective, but represents a significant risk in terms of partners' selection in the chain. In fact, the strength of the chain is determined by the strength of its weakest link. Digital economy is based on the technology, but it cannot exist without strong partners' relationships and trust. It erases the boundaries between companies and customers, and integrates customers within the organization, making them part of the value chain. From the previous development of CRM, it is evident that this concept will continue its evolution in the future. It is assumed that the CRM will include managing relationships with partners within the value chain (VCRM-Value Chain Relationship Management) and managing relationships with customer communities (CCRM-Customer Community Relationship Management) ${ }^{7}$. Thereby customer relationship management will involve a broader context, but also a greater role and significance in modern business and the new economy.

\section{Conclusion}

Modern, Internet-based, business requires from the company to find new ways of creating and maintaining relationships with customers. Customer Relationship Management includes an

\footnotetext{
${ }^{6}$ Panian Ž., (2002), Izazovi elektroničnog poslovanja, (1st edition), Narodne novine, ISBN: 9536053632, Zagreb, pp.154.

7 Fingar P., \& Aronica R. (2001). The death of "e" and the birth of the real new economy: Business models, technologies and strategies for the 21st century, (1st edition), Meghan-Kiffer Press, ISBN:0929652-20-7, Tampa, Florida, pp.86.
} 
iterative (repetitive) process by which the information collected about customers are converted to positive relationships with them. Establishing direct and two-way communication is especially important in global competitive environment. In terms of stiff competition and global availability of information, products and services, customers expect continuous communication with the company and superior compliance with their requirements. Therefore, every company that is part of "e-story," must strive to offer high quality and customized products and services, and a range of additional benefits that will attract new and retain existing customers. For this reason, companies need to manage relationships with customers to increase their competitiveness and strengthen market position. The development of information technologies has significantly improved the relations between companies and their customers. In fact, modern information technology is a powerful instrument that enhances communication between the company's employees and its customers, but also effectiveness of the management within the company. The most prominent IT feature, in terms of customer relationship management, is enabling the interactive communication. This improves value creation for customers. The possibility of direct and targeted customer relations, leads to their personalization. Multi-channel communication facilitate the establishment of more sophisticated and two-way relationships, but it makes more difficult to integrate data and create unique images of customers. Therefore, the collected and stored data about customers must be available and integrated within the entire organization. This goal can be realized by building the functional customer data warehouse. In this way, the data warehouse represents the information core of Customer Relationship Management system. Data quality and availability in the warehouse enables offering adequate products and/or services to the customers. It is the backbone of the entire information infrastructure and associated technologies for decision support. Without the functional data warehouse, there are no integration of data as the foundation of successful relationships with customers or acquiring new knowledge in the form of business intelligence, which involves the provision of better information. The biggest advantage of business intelligence application in customer relationship management is its foundation in personalization. Personalized relationships with customers provide companies to better understand and satisfy the needs of each customer. This ensures that each customer gets exactly what wants and when it wants. BI applications support the implementation of various channels of communication with clients, such as e-mail, Web, telephone, etc. Customers in accordance with their preferences, choose the channel that best suits them and by whom will receive a personalized message. In addition, by possession of complete information about all performed transactions and customers' experiences, companies can deliver added value and achieve their satisfaction. On the other hand, business intelligence application improves creation a real and complete image of the client, which will provide faster, better and easier decision making. Complementary use of CRM systems and Business Intelligence, provides a holistic approach to customers which includes improvements in customer profiling, simpler detection value for customers, measuring the success of the company in satisfying its customers, and creating a comprehensive customer relationship management. Business Intelligence can detect various incentives to increase sales and revenue, such as faster conversion of potential into actual clientss, reducing the number of outgoing customers and increase sales to existing customers. Therefore, this chapter can be summarized at the main learning objectives. Namely, after completion of this chapter, you will be able to: 
1. Recognize essential value of customers to the enterprise;

2. Identify role of Business Intelligence in long term customer relationships;

3. Define Business Intelligence and explain its architecture;

4. Understand importance of CRM philosophy in the global competitive environment;

5. Describe multidimensional communication with customers;

6. Explain significance of data integration in providing unique experience for customers;

7. Understand social media advantages in advertising and loyalty programs;

8. Identify perspectives of the customer relationship management's evolution.

\section{References}

Baars H., \& Kemper H.G., (2008), Management support with structured and unstructured data - an integrated business intelligence framework, Information Systems Management, Vol.25, Issue 2., March 2008., pp.132-148., ISSN: 1058-0530.

Blackwell R.D., \& Stephan K., (2001), Customers rule: why the e-commerce honeymoon is over and where winning businesses go from here, Crown Business, ISBN 0-609-60865-7, New York.

Boysen M., (2008), Why is a CRM Strategy important?, 01/30/2010, Available from: http://it.toolbox.com/blogs/effectivecrm/why-is-a-crm-strategy-important-26837.

Burnett K., (2001), The handbook of key customer relationship management: the definitive guide to winning, managing and developing key account business, (1st edition), Financial Times Prentice Hall, ISBN: 9780273650317, Great Britain.

CMO Survey, (2009), Marketers Prepare for Better Times Ahead, Duke University, 08/01/2011, Available from: http:/ / news.duke.edu/2009/08/cmo.html

Dyche J., (2002), The CRM Handbook: A business Guide to Customer Relationships Management, (1st edition), Addison-Wesley Professional, ISBN: 978-0201730623, USA.

Fingar P., \& Aronica R. (2001). The death of " $e$ " and the birth of the real new economy: Business models, technologies and strategies for the 21st century, (1st edition), Meghan-Kiffer Press, ISBN:0-929652-20-7, Tampa, Florida.

Greenberg P., CRM at the Speed of Light: Social CRM 2.0 Strategies, Tools, and Techniques for Engaging Your Customers, (4th edition), McGraw-Hill Osborne Media, ISBN: 9780071590457, USA.

Habul A., \& Pilav-Velić A., (2010), Business Intelligence and Customer Relationship Management, Proceedings of 32nd International Conference on Information Technology Interfaces ITI 2010, ISBN 978-953-7138-19-6, Cavtat-Croatia, June 2010.

Inmon W. H., (1996), Building the Data Warehouse, (2nd edition), John Wiley \& Sons, ISBN: 978-0471141617, USA.

Inmon W. H., (2005), Building the Data Warehouse, (4th edition), John Wiley \& Sons, ISBN: 978-0764599446, USA.

Kalakota R., \& Robinson M., (2000), E-Business 2.0: Roadmap for Success, (2nd edition), Addison-Wesley Professional, ISBN: 978-0201721652, London.

Kelly K., (1999), New Rules for the New Economy, (1st edition), Penguin Books, ISBN: 9780140280609, USA.

Kotler P., \& Armstrong G., (2003), "Principles of Marketing“, (10th edition), Prentice Hall, ISBN: 978-0131018617, USA.

Lane N., (1999), Advancing the Digital Economy into 21st Century, Information Systems Frontiers, Vol.1., Issue 3., October 1999., pp.317-320., ISSN:1387-3326. 
Middlebrooks A., \& Craig T., (1999), Market Leadership Strategies for Service Companies: Creating Growth, Profits and Customer Loyalty, (1st edition), McGraw Hill, ISBN: 9780844224411, USA.

Murfitt S., (2001), Using Business Intelligence, 07/05/2010, Available from: www.digitrends/net/scripts

Nielsen company, (August 2, 2010), What Americans Do Online: Social Media And Games Dominate Activity, Nielsen Online, 07/15/2011, Available from: http://blog.nielsen.com/nielsenwire/online_mobile/what-americans-do-onlinesocial-media-and-games-dominate-activity/

Panian Ž., (2003), Odnosi s klijentima u e-poslovanju, (1st edition), Sinergija, ISBN 953-6895-110 , Zagreb.

Panian Ž., (2002), Izazovi elektroničnog poslovanja, (1st edition), Narodne novine, ISBN: 9536053632, Zagreb.

Peppers D., \& Rogers M., (2004), Managing Customer Relationship: a strategic framework, (1st edition), John Wiley \& Sons Inc., ISBN: 978-0471485902, New Jersey.

Prahalad C.K., Ramaswamy P.B., Katzenbach J.R., Lederer Ch., \& Hill S.,(2002), Harvard Business Review on Customer Relationship Management, (1st edition), Harvard Business Press, ISBN: 978-1578516995, USA.

Reynolds G.W., (1995), Information Systems for Managers, (3rd edition), West Publishing Co., ISBN: 0-314-04597-X, USA.

Reynolds J.A., (2002), "Practical Guide to CRM“, (1st edition), CMP Books, ISBN: 9781578201020, New York, USA.

Turban E., \& Volonino L., (2010.), Business Intelligence and Decision Support Systems, Information Technology for Management: Transforming Organizations in the Digital Economy, pp. 445-484, (7th edition ), John Wiley \& Sons, ISBN: 978-0470400326, USA.

Turban E., Sharda R., Delen D., \& King D., (2010), Business Intelligence, (2nd edition), Prentice Hall, ISBN: 978-0136100669, USA.

Vercellis C., (2009), Business Intelligence: Data Mining and Optimization for Decision Making, (1st edition), Wiley, ISBN: 978-0470511398, USA.

Wiliamson D. A., (2009), Social Network Ad Spending: 2010 Outlook, eMarketer Inc, 07/20/2011, Available from:

http://www.emarketer.com/Reports/All/Emarketer_2000621.aspx 


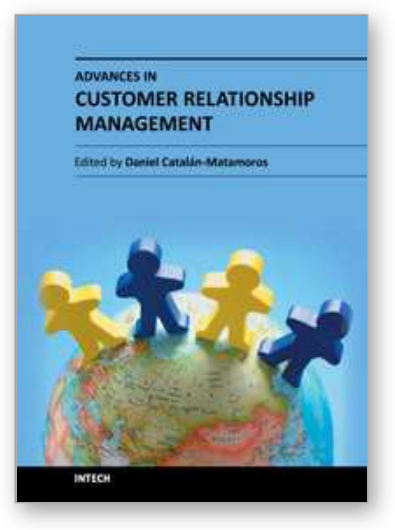

\author{
Advances in Customer Relationship Management \\ Edited by Dr. Daniel Catalan-Matamoros
}

ISBN 978-953-51-0516-9

Hard cover, 146 pages

Publisher InTech

Published online 11, April, 2012

Published in print edition April, 2012

Customer relationship management (CRM) strategies have become increasingly important worldwide due to changes in expectations from customers as well as changes in the nature of markets. This book puts forth a conceptualization that attempts to not only outline CRM's domain but also to reconcile the divergent perspectives found in the academic and popular literature. Readers can see through measurable datacontaining examples how the theory is applied with great success by various real-life examples. This book presents innovative proven methods for determining whether a CRM strategy for changing the way a company provides service (by adding new technology, processes, and procedures) will realize the return on the investment projected. It could be a great help to CRM personnel, student, managers and any one that works directly or indirectly with customers.

\title{
How to reference
}

In order to correctly reference this scholarly work, feel free to copy and paste the following:

Aida Habul and Amila Pilav-Velić (2012). Customer Relationship Management and Business Intelligence, Advances in Customer Relationship Management, Dr. Daniel Catalan-Matamoros (Ed.), ISBN: 978-953-510516-9, InTech, Available from: http://www.intechopen.com/books/advances-in-customer-relationshipmanagement/business-intelligence-and-customer-relationship-management

\section{INTECH}

open science | open minds

\author{
InTech Europe \\ University Campus STeP Ri \\ Slavka Krautzeka 83/A \\ 51000 Rijeka, Croatia \\ Phone: +385 (51) 770447 \\ Fax: +385 (51) 686166 \\ www.intechopen.com
}

\author{
InTech China \\ Unit 405, Office Block, Hotel Equatorial Shanghai \\ No.65, Yan An Road (West), Shanghai, 200040, China \\ 中国上海市延安西路65号上海国际贵都大饭店办公楼 405 单元 \\ Phone: +86-21-62489820 \\ Fax: +86-21-62489821
}


(C) 2012 The Author(s). Licensee IntechOpen. This is an open access article distributed under the terms of the Creative Commons Attribution 3.0 License, which permits unrestricted use, distribution, and reproduction in any medium, provided the original work is properly cited. 